\title{
Mucilaginibacter frigoritolerans sp. nov., Mucilaginibacter lappiensis sp. nov. and Mucilaginibacter mallensis sp. nov., isolated from soil and lichen samples
}

\author{
Correspondence \\ Minna K. Männistö \\ minna.mannisto@metla.fi
}

\author{
Minna K. Männistö, ${ }^{1}$ Marja Tiirola, ${ }^{2}$ Jennifer McConnell ${ }^{3}$ \\ and Max M. Häggblom ${ }^{3}$
${ }^{1}$ Finnish Forest Research Institute, Eteläranta 55, Fl-96300 Rovaniemi, Finland Finland
${ }^{3}$ Department of Biochemistry and Microbiology, Rutgers University, 76 Lipman Drive, New Brunswick, NJ 08901, USA \\ ${ }^{2}$ Department of Biological and Environmental Science, University of Jyväskylä, Fl-40014 Jyväskylä,
}

The genus Mucilaginibacter of the family Sphingobacteriaceae was described by Pankratov et al. (2007) and at present comprises seven species: Mucilaginibacter paludis and Mucilaginibacter gracilis (Pankratov et al., 2007), Mucilaginibacter kameinonensis (Urai et al., 2008), Mucilaginibacter daejeonensis (An et al., 2009), Mucilaginibacter ximonensis (Luo et al., 2009), Mucilaginibacter oryzae (Jeon et al., 2009) and Mucilaginibacter rigui (Baik et al., 2010). Members of the family Sphingobacteriaceae are commonly isolated from cold environments such as alpine (Margesin et al., 2003; Shivaji et al., 2005) and tundra soil (Männistö \& Häggblom, 2006). Terminal restriction fragment analysis coupled to clone

\section{Abbreviation: TEM, transmission electron microscopy.}

The GenBank/EMBL/DDBJ accession numbers for the $16 \mathrm{~S}$ rRNA gene sequences of strains MP601, ANJLI2 ${ }^{\top}$, RA1BR4, FT22 ${ }^{\top}$ and MP1X $4^{\top}$ are FN400858, DQ234446, DQ234507, FN400860 and FN400859, respectively.

Electron micrographs (Supplementary Fig. S1) and differential features (Supplementary Table S1) of the novel isolates are available with the online version of this paper. libraries of soil DNA and rRNA has indicated that bacteria of the family Sphingobacteriaceae are dominant members of the Arctic tundra of Finland and retain high activity at low temperatures and after multiple freeze-thaw cycles (Männistö et al., 2009). Through cultivation of soil and lichen samples from northern Finland on various media, we have amassed a collection of more than 50 mucoid Gram-negative strains that are non-pigmented, yellowpigmented or red-pigmented when grown on R2A agar and contain high amounts of iso/anteiso and branched-chain hydroxy fatty acids (Männistö \& Häggblom, 2006; M. K. Männistö, unpublished results). Analysis of 16S rRNA gene sequences indicated that these strains represent a wide diversity of species within the family Sphingobacteriaceae and are related to various species of the genera Pedobacter and Mucilaginibacter. These isolates appear well-adapted to the low temperature environment where they are exposed not only to sub-zero temperatures but also to desiccation and a wide regime of annual temperature variation. In this paper, five strains isolated from samples collected in Finnish Lapland are described. Based on phenotypic and 
phylogenetic analysis, these isolates represent novel members of the genus Mucilaginibacter.

Strains ANJLI2 ${ }^{\mathrm{T}}$ and RA1BR4 originated from oligotrophic lichen-dominated Scots pine forests located in Angeli $\left(68^{\circ}\right.$ $\left.57^{\prime} \mathrm{N} 25^{\circ} 53^{\prime} \mathrm{E}\right)$ and Rajajooseppi (68 $\left.28^{\circ} 28^{\prime} \mathrm{N} 28^{\circ} 28^{\prime} \mathrm{E}\right)$, respectively. Strain ANJLI2 ${ }^{\mathrm{T}}$ was isolated from a decaying lichen using lichenin as the growth substrate as described previously (Männistö \& Häggblom, 2006). Strain RA1BR4 was isolated from a soil sample collected under a thick lichen layer after incubation at $15{ }^{\circ} \mathrm{C}$ on R2A (Difco) plates as described previously (Männistö \& Häggblom, 2006). Strains MP601 and MP1X4 ${ }^{\mathrm{T}}$ were isolated from Arctic-alpine tundra soil (elevation approx. $700 \mathrm{~m}$ above sea-level) collected from Malla nature reserve located in Kilpisjärvi, in the far north-western part of Finland $\left(69^{\circ} 01^{\prime} \mathrm{N} 20^{\circ} 50^{\prime}\right.$ E), using R2A agar (Difco) and xylan agar, respectively. The xylan agar contained birchwood xylan $\left(0.6 \mathrm{~g} \mathrm{l}^{-1}\right)$, yeast extract $\left(0.3 \mathrm{~g} \mathrm{l}^{-1}\right)$ and agar $\left(15 \mathrm{~g} \mathrm{l}^{-1}\right)$ in VL55 buffer, pH 5.5 (Sait et al., 2002). Strain FT $22^{\mathrm{T}}$ was isolated from tundra soil (Malla nature reserve) microcosm after two freeze-thaw cycles at $-3{ }^{\circ} \mathrm{C}$ (Männistö et al., 2009). All strains were maintained on R2A agar ( $\mathrm{pH}$ 5.5-7.0).

Genomic DNA was extracted using an UltraClean microbial isolation DNA kit (MoBio Laboratories). Nearly complete 16S rRNA genes were amplified using universal primer set $27 \mathrm{~F}$ and $1387 \mathrm{r}$ as described previously (Männistö \& Häggblom, 2006). The sequencing of both strands was performed using five internal $16 \mathrm{~S}$ rRNA gene specific primers, the BigDye terminator cycle sequencing kit version 2.1 (PE Applied Biosystems) and an Applied Biosystems model 3100 sequencer. Sequencing reactions were compiled using the program package Vector NTI (Invitrogen) and sequences were compared with those available in GenBank using the program BLAST (Altschul et al., 1997). Multiple alignments and phylogenetic trees were reconstructed using the program package MEGA4 (Tamura et al., 2007) with the maximum composite likelihood model for nucleotide substitutions (Tamura et al., 2004).
Comparative 16S rRNA gene sequence analysis showed that the novel cold-adapted strains represent three new branches within the genus Mucilaginibacter. Strains ANJLI2 $^{\mathrm{T}}$, MP601 and RA1BR4 had identical 16S rRNA gene sequences, whereas strains $\mathrm{FT} 22^{\mathrm{T}}$ and $\mathrm{MP} 1 \mathrm{X} 4^{\mathrm{T}}$ differed from the other strains. The sequences of strains FT $22^{\mathrm{T}}$ and MP1X $4^{\mathrm{T}}$ had similarities of $94.8 \%$ and $96.4 \%$, respectively, with that of ANJLI2 ${ }^{\mathrm{T}}$, whereas the sequences of strains $\mathrm{FT} 22^{\mathrm{T}}$ and $\mathrm{MP} 1 \mathrm{X} 4^{\mathrm{T}}$ shared $95.7 \%$ similarity. The closest relatives of strains ANJLI2 ${ }^{\mathrm{T}}$, MP601 and RA1BR4 were the type strains of $M$. rigui ( $96.3 \%$ similarity), $M$. ximonensis (95.1\%) and M. paludis (94.9\%). Strain $\mathrm{MP} 1 \mathrm{X} 4^{\mathrm{T}}$ was most closely related to the type strains of M. paludis (95.3\% similarity), M. rigui $(95.2 \%), M$. ximonensis $(95.2 \%)$, M. gracilis $(95.0 \%)$ and M. daejeonensis $(94.7 \%)$, whereas strain $\mathrm{FT} 22^{\mathrm{T}}$ was most closely related to the type strains of $M$. oryzae ( $94.9 \%$ similarity), M. paludis $(94.9 \%)$, M. rigui $(94.6 \%)$ and $M$. gracilis $(94.6 \%)$. In the phylogenetic tree (Fig. 1), all of the studied strains clearly belonged to the lineage defined by the genus Mucilaginibacter of the family Sphingobacteriaceae. Strains ANJLI2 ${ }^{\mathrm{T}}$, MP601 and RA1BR4 clustered most closely with M. rigui, which was supported by high bootstrap values in both the neighbour-joining and maximum-parsimony analyses. Strains $\mathrm{FT} 22^{\mathrm{T}}$ and $\mathrm{MPIX} 4^{\mathrm{T}}$ also clustered with $M$. rigui in the neighbour-joining analysis, but this was not supported by high bootstrap values or the maximumparsimony analysis.

Cellular morphology of the strains was studied by phasecontrast microscopy after 2-14 days cultivation on R2A at $20{ }^{\circ} \mathrm{C}$ using a Leitz Laborlux $\mathrm{S}$ light microscope. In addition, cells of strains ANJLI2 ${ }^{\mathrm{T}}, \mathrm{FT} 22^{\mathrm{T}}$ and $\mathrm{MP} 1 \mathrm{X} 4^{\mathrm{T}}$ were examined using transmission electron microscopy (TEM). For TEM analysis, strains were grown in R2A broth at $4{ }^{\circ} \mathrm{C}$ and $21{ }^{\circ} \mathrm{C}$ for 7 and 2 days, respectively, and cells were fixed with $3 \%$ glutaraldehyde and negatively stained. Gram-staining was performed using the Hucker staining method (Murray et al., 1994). On R2A agar (pH 6), strains ANJLI2 ${ }^{\mathrm{T}}$, MP601 and RA1BR4 formed small, circular, convex colonies with diameters of $1-3 \mathrm{~mm}$. The colony

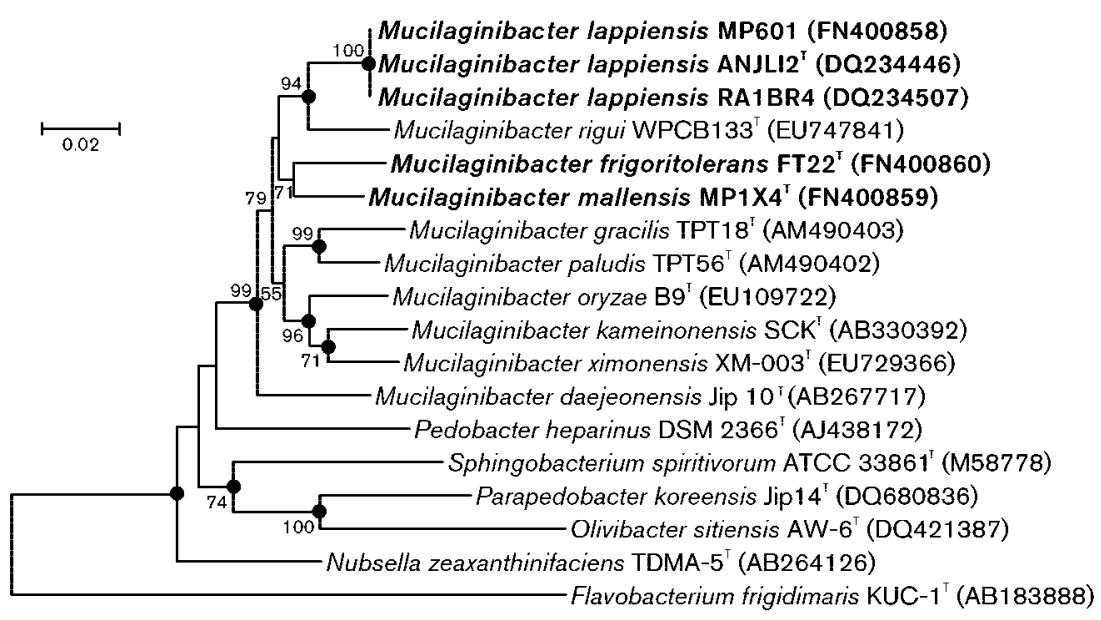

Fig. 1. Neighbour-joining phylogenetic tree based on 16S rRNA gene sequences (1327 nt positions) showing the relationships between $M$. frigoritolerans, $M$. lappiensis and M. mallensis strains, other species of the genus Mucilaginibacter and related taxa. Bootstrap values (expressed as percentages of 1000 replicates) of $>50 \%$ are shown at branch points. Solid circles indicate that the corresponding nodes (groupings) were also recovered in the maximum-parsimony tree. Bar, 0.02 substitutions per nucleotide position. 
colour varied from light pink to reddish. Strains MP1X4 $4^{\mathrm{T}}$ and $\mathrm{FT} 22^{\mathrm{T}}$ formed larger (up to $5 \mathrm{~mm}$ diameter) convex, circular and mucoid colonies that were pale yellow to yellow in colour. All strains also grew well on plate count agar (BD) at pH 6.5. Strains ANJLI2 ${ }^{\mathrm{T}}$, MP601 and RA1BR4 grew well on tryptic soy broth agar (BD) at $\mathrm{pH} 6.5$, whereas strain MP1X4 $4^{\mathrm{T}}$ grew weakly and strain $\mathrm{FT} 22^{\mathrm{T}}$ did not grow. Cells of all strains were Gram-stain-negative, non-spore-forming, non-motile rods that occurred singly or in pairs. Cells were generally $1-5 \mu \mathrm{m}$ long, but young cultures (1-2 days) of strains MP1X4 ${ }^{\mathrm{T}}, \mathrm{ANJLI} 2^{\mathrm{T}}, \mathrm{MP} 601$ and RA1BR4 occasionally contained cells of $5-15 \mu \mathrm{m}$ in length or up to $40 \mu \mathrm{m}$ long chains of cells. Old cultures (2 weeks) of all strains contained shorter $(0.5-3.0 \mu \mathrm{m})$ cells. Spherical vesicle structures that resembled the Lforms reported in M. paludis and M. gracilis (Pankratov et al., 2007) were detected in 2-week-old cultures. TEM examination revealed that the cells did not have flagella or fimbria, but the construction of the outer membrane of strain MPIX $4^{\mathrm{T}}$ occasionally resembled pilus-like filaments with a spherical vesicle in the end (see Supplementary Fig. S1 available in IJSEM Online).

Growth of the novel isolates at different temperatures $(-3$ to $\left.+35{ }^{\circ} \mathrm{C}\right)$ and $\mathrm{NaCl}$ concentrations $(0-3 \%)$ was tested on $\mathrm{R} 2 \mathrm{~A}$ agar ( $\mathrm{pH} \mathrm{6)}$. The optimum growth temperature and $\mathrm{pH}$ were tested on $\mathrm{R} 2 \mathrm{~A}$ broth at $18,21,25$ and $28{ }^{\circ} \mathrm{C}$ and between $\mathrm{pH} 4.0$ and 9.0. Strains ANJLI2 ${ }^{\mathrm{T}}$, MP601 and RA1BR4 grew at $\mathrm{pH} 4.5-8.0$ and at temperatures of 0 $31{ }^{\circ} \mathrm{C}$. Strain MP1X4 ${ }^{\mathrm{T}}$ grew at $\mathrm{pH} 4.5-7.0$ and at -3 to $33{ }^{\circ} \mathrm{C}$, whereas strain FT22 $2^{\mathrm{T}}$ grew at $\mathrm{pH} 5.0-7.0$ and at 0 $33{ }^{\circ} \mathrm{C}$. Optimum growth of all strains was observed at $25^{\circ} \mathrm{C}$ and $\mathrm{pH}$ 6.0. Strains ANJLI2 ${ }^{\mathrm{T}}$, MP601 and RA1BR4 grew well at $\mathrm{NaCl}$ concentrations of $1.5 \%$, whereas growth of strains $\mathrm{MP} 1 \mathrm{X} 4^{\mathrm{T}}$ and $\mathrm{FT} 22^{\mathrm{T}}$ was inhibited at $\mathrm{NaCl}$ concentrations $>1 \%$. Flexirubin-type pigments were detected in strains $\mathrm{FT} 22^{\mathrm{T}}$ and MP1X4 ${ }^{\mathrm{T}}$ using the bathochromic shift test with $20 \% \mathrm{KOH}$ (Bernardet et al., 2002). All five strains were positive for oxidase and catalase activities as determined using Bactident Oxidase strips and Bactident 3\% hydrogen peroxide solution (Merck), respectively. The assimilation of various carbon sources was tested after up to 7 days of incubation at $20{ }^{\circ} \mathrm{C}$ on API 50 and API 20NE strips (bioMérieux), Biolog GN Microplates and on 96-well plates with DSM 465 mineral medium ( $\mathrm{pH} \mathrm{6)}$ supplemented with yeast extract $\left(50 \mathrm{mg} \mathrm{l}^{-1}\right.$ ) and $10 \mathrm{mM}$ of each carbon source. Acid production from carbohydrates was examined using API 50 strips that were inoculated with cultures suspended in MM1 medium (Pankratov et al., 2007) at pH 6.8 and supplemented with $0.5 \mathrm{~g}$ yeast extract $\mathrm{l}^{-1}$. After 3 days of incubation at room temperature $\left(22 \pm 1{ }^{\circ} \mathrm{C}\right), 25 \mu \mathrm{l}$ methyl red $(0.1 \%)$ was added to the cupules as a $\mathrm{pH}$ indicator. The formation of red colour indicated a positive reaction, whereas an orange colour indicated a weak positive reaction compared to the yellow colour of the control (i.e. no substrate). Enzymic activities in all novel isolates were assayed after $48 \mathrm{~h}$ of incubation using the API ZYM kits (bioMérieux). Hydrolysis of CM-cellulose, birchwood xylan and lichenin (main polysaccharide in lichen) was tested on agar plates following Congo red staining after 314 days of incubation at room temperature as described previously (Männistö \& Häggblom, 2006).

The DNA G + C contents of the strains were determined following the method of Mesbah et al. (1989). Genomic DNA was extracted and purified by phenol/chloroform extraction using a method modified from Kerkhof \& Ward (1993). RNase A (50 $\left.\mu \mathrm{g} \mathrm{ml}^{-1}\right)$ was added and the mixture was incubated at $37{ }^{\circ} \mathrm{C}$ for $30 \mathrm{~min}$, followed by addition of $50 \mu \mathrm{l} 10 \%$ SDS and $50-100 \mu \mathrm{l}$ of $100 \mu \mathrm{g}$ proteinase $\mathrm{K} \mathrm{ml}^{-1}$ and incubation at $37{ }^{\circ} \mathrm{C}$ for $1-12 \mathrm{~h}$ until loss of turbidity and viscosity was observed. The DNA G+C content $(\mathrm{mol} \%)$ was determined by HPLC using the method described by Mesbah et al. (1989) with the following modifications: a Synergi $4 \mathrm{U}$ Fusion-RP $80 \mathrm{~A} \mathrm{C} \mathrm{C}_{18}$ reverse phase column (Phenomenex) was used in a Shimadzu HPLC (model LC-10AS) system. The eluent consisted of $7 \% 20 \mathrm{mM}$ ammonium acetate $(\mathrm{pH} 4.5)$ and $93 \%$ acetonitrile at a flow rate of $1 \mathrm{ml} \mathrm{min}^{-1}$. Nucleosides were detected at a wavelength of $260 \mathrm{~nm}$. Salmon sperm DNA was used for calibration and Escherichia coli DNA was used as a control. The range of DNA G $+\mathrm{C}$ contents (44.0$46.5 \mathrm{~mol} \%$ ) was similar to that of other species of the genus Mucilaginibacter (Table 1).

Cellular fatty acids and respiratory quinones were analysed from cells grown on $\mathrm{R} 2 \mathrm{~A}(\mathrm{pH} 6)$ at $20{ }^{\circ} \mathrm{C}$ for 3 days. Analysis of respiratory quinones of strains ANJLI2 ${ }^{\mathrm{T}}, \mathrm{FT} 22^{\mathrm{T}}$ and MP1X $4^{\mathrm{T}}$ was carried out by the Identification Service and Dr B. J. Tindall, DSMZ, Braunschweig, Germany. Total fatty acids were methylated and analysed as described previously (Männistö \& Häggblom, 2006) using an HP 5890 series II GC (Hewlett Packard) equipped with Sherlock MIDI Software. The identification of fatty acid methyl esters was also confirmed using an HP GCD Plus GC-MS. The major cellular fatty acids $(>4 \%)$ of the five strains were: summed feature $3\left(\mathrm{C}_{16: 1} \omega 7 c /\right.$ iso- $\left.\mathrm{C}_{15: 0} 2-\mathrm{OH}\right)$, iso- $\mathrm{C}_{15: 0}$, iso- $\mathrm{C}_{17: 0} 3-\mathrm{OH}, \mathrm{C}_{16: 1} \omega 5 c$ and $\mathrm{C}_{16: 0}$ (Table 2). Although phylogenetic analysis indicated a close relationship between the novel isolates and Mucilaginibacter rigui, the fatty acid composition of the isolates was clearly distinguishable from that of M. rigui. M. rigui contained high amounts of anteiso$\mathrm{C}_{15: 0}$, whereas only traces of summed feature 3 were detected (Table 2). All five strains reported here contained $>30 \%$ summed feature 3 fatty acids $\left(\mathrm{C}_{16: 1} \omega 7 \mathrm{c}\right.$ and iso$\mathrm{C}_{15: 0} 2-\mathrm{OH}$ in approximately equal amounts) and only traces of anteiso- $\mathrm{C}_{15: 0}$. The major respiratory quinone of strains ANJLI2 ${ }^{\mathrm{T}}, \mathrm{FT} 22^{\mathrm{T}}$ and $\mathrm{MP} 1 \mathrm{X} 4^{\mathrm{T}}$ was menaquinone-7 (MK-7); minor quantities (2-3\%) of MK-6 were detected in all three strains.

Phylogenetic analysis, DNA G+C content (44.0$46.5 \mathrm{~mol} \%$ ), major cellular fatty acids (iso- $\mathrm{C}_{15: 0}$, summed feature 3 and iso- $\mathrm{C}_{17: 0} 3-\mathrm{OH}$ ) and $\mathrm{MK}-7$ as the major quinone associated the strains with members of the genus Mucilaginibacter. However, the degree of 16S rRNA gene 
Table 1. Physiological characteristics of the novel isolates and the type strains of species of the genus Mucilaginibacter

Strains: 1, ANJLI2 ${ }^{\mathrm{T}}$; 2, RA1BR4; 3, MP601; 4, FT22 ${ }^{\mathrm{T}} ; 5$, MP1X4 ${ }^{\mathrm{T}} ; 6$, M. paludis TPT56 ${ }^{\mathrm{T}}$ (data from Pankratov et al., 2007); 7, M. gracilis TPT18 ${ }^{\mathrm{T}}$ (Pankratov et al., 2007); 8, M. daejeonensis Jip $10^{\mathrm{T}}$ (An et al., 2009); 9, M. ximonensis XM-003 ${ }^{\mathrm{T}}$ (Luo et al., 2009); 10, M. oryzae B9 ${ }^{\mathrm{T}}$ (Jeon et al., 2009); 11, M. rigui WPCB133 ${ }^{\mathrm{T}}$ (Baik et al., 2010); 12, M. kameinonensis $\mathrm{SCK}^{\mathrm{T}}$ (Urai et al., 2008). All strains are positive for acid production from cellobiose, galactose and maltose and catalase and oxidase activities. All strains are negative for Gram-staining and indole production. +, Positive; -, negative; w, weakly positive reaction; NA, data not available.

\begin{tabular}{|c|c|c|c|c|c|c|c|c|c|c|c|c|}
\hline Characteristic & 1 & 2 & 3 & 4 & 5 & 6 & 7 & 8 & 9 & 10 & 11 & 12 \\
\hline Isolation source & Lichen & $\begin{array}{c}\text { Tundra } \\
\text { soil }\end{array}$ & $\begin{array}{c}\text { Forest } \\
\text { soil }\end{array}$ & $\begin{array}{l}\text { Freeze- } \\
\text { thaw- } \\
\text { treated } \\
\text { tundra soil }\end{array}$ & $\begin{array}{c}\text { Tundra } \\
\text { soil }\end{array}$ & Peat bog & Peat bog & $\begin{array}{l}\text { Dried } \\
\text { rice } \\
\text { straw }\end{array}$ & $\begin{array}{c}\text { Tibetan } \\
\text { soil }\end{array}$ & $\begin{array}{l}\text { Rice } \\
\text { paddy } \\
\text { soil }\end{array}$ & $\begin{array}{l}\text { Wetland } \\
\text { freshwater }\end{array}$ & $\begin{array}{c}\text { Garden } \\
\text { soil }\end{array}$ \\
\hline $\begin{array}{l}\text { Growth temperature } \\
\text { range }\left({ }^{\circ} \mathrm{C}\right)\end{array}$ & $0-31$ & $0-31$ & $0-31$ & $0-33$ & -3 to 33 & $2-33$ & $2-33$ & $15-37$ & $10-33$ & $15-35$ & $4-37$ & $5-30$ \\
\hline $\mathrm{pH}$ range & $4.5-8.0$ & $4.5-8.0$ & $4.5-8.5$ & $5.0-7.0$ & $4.5-7.0$ & $4.2-8.2$ & $4.2-8.2$ & $4.5-8.5$ & $5.0-8.0$ & $5.0-8.0$ & $5.0-10.0$ & $4.0-9.0$ \\
\hline Pigment & $\begin{array}{r}\text { Pale } \\
\text { red }\end{array}$ & $\begin{array}{r}\text { Pale } \\
\text { red }\end{array}$ & $\begin{array}{r}\text { Pale } \\
\text { red }\end{array}$ & Yellow & $\begin{array}{l}\text { Pale } \\
\text { yellow }\end{array}$ & Pink & $\begin{array}{l}\text { Yellow/ } \\
\text { orange }\end{array}$ & Orange & $\begin{array}{l}\text { Pale } \\
\text { yellow }\end{array}$ & $\begin{array}{l}\text { Pale } \\
\text { pink }\end{array}$ & $\begin{array}{l}\text { Pale } \\
\text { pink }\end{array}$ & $\begin{array}{l}\text { Pale } \\
\text { pink }\end{array}$ \\
\hline $\begin{array}{l}\text { Flexirubin-type } \\
\text { pigments }\end{array}$ & - & - & - & + & + & - & - & $\mathrm{NA}$ & - & - & - & + \\
\hline Oxidase activity & + & + & + & + & + & + & + & + & + & + & + & - \\
\hline Nitrate reduction & - & - & - & - & + & - & - & - & - & - & - & - \\
\hline $\begin{array}{l}\text { Growth with }>1 \% \\
\mathrm{NaCl}\end{array}$ & + & + & + & - & - & - & - & + & - & + & - & - \\
\hline Hydrolysis of aesculin & + & + & + & + & + & - & - & + & + & + & + & + \\
\hline Hydrolysis of gelatin & + & + & + & - & - & $\mathrm{NA}$ & NA & NA & $\mathrm{NA}$ & + & - & NA \\
\hline Arginine dihydrolase & + & + & + & - & - & NA & NA & + & - & NA & - & - \\
\hline $\mathrm{H}_{2} \mathrm{~S}$ production & - & - & - & - & - & - & - & $\mathrm{NA}$ & - & - & - & - \\
\hline \multicolumn{13}{|l|}{ Assimilation of: } \\
\hline Acetic acid & - & - & - & - & - & - & - & - & + & + & - & - \\
\hline Dextrin & + & + & + & + & - & $\mathrm{NA}$ & NA & $\mathrm{NA}$ & + & + & + & + \\
\hline Glycogen & - & - & - & + & - & NA & NA & - & - & + & - & + \\
\hline D-Glucose & + & + & + & + & + & + & + & + & - & - & + & + \\
\hline D-Mannose & + & + & + & + & + & + & - & + & + & + & + & + \\
\hline Sucrose & + & + & + & + & + & + & + & + & - & - & + & + \\
\hline Gluconic acid & - & - & - & - & - & + & - & NA & NA & + & - & - \\
\hline Melibiose & + & + & + & + & + & - & - & - & - & + & + & + \\
\hline Raffinose & + & + & + & - & - & - & + & NA & + & + & + & + \\
\hline myo-Inositol & - & - & - & - & - & + & - & - & - & - & - & - \\
\hline $\begin{array}{l}\mathrm{N} \text {-Acetyl-D- } \\
\text { galactosamine }\end{array}$ & + & + & + & - & - & NA & $\mathrm{NA}$ & NA & - & - & - & - \\
\hline $\begin{array}{l}N \text {-Acetyl-D- } \\
\text { glucosamine }\end{array}$ & + & + & + & + & + & + & - & + & + & $\mathrm{w}$ & + & $\mathrm{w}$ \\
\hline D-Galacturonic acid & - & - & - & - & - & + & - & $\mathrm{NA}$ & - & - & - & - \\
\hline \multicolumn{13}{|l|}{ Acid production from: } \\
\hline D-Arabinose & + & + & + & - & - & $\mathrm{NA}$ & NA & + & NA & $\mathrm{NA}$ & - & + \\
\hline L-Arabinose & - & - & - & + & + & NA & NA & + & NA & + & - & + \\
\hline D-Glucose & + & + & + & + & + & + & + & + & - & + & - & + \\
\hline D-Fructose & - & - & - & $\mathrm{w}$ & + & + & + & + & + & + & - & + \\
\hline D-Mannose & $\mathrm{w}$ & $\mathrm{w}$ & $\mathrm{w}$ & + & + & + & - & + & + & + & + & + \\
\hline Melezitose & - & - & - & + & - & NA & NA & - & - & NA & - & + \\
\hline Melibiose & + & + & + & + & + & - & - & + & $\mathrm{w}$ & + & + & + \\
\hline L-Rhamnose & - & - & - & - & - & + & - & + & NA & NA & - & - \\
\hline Sucrose & + & $\mathrm{w}$ & $\mathrm{w}$ & + & + & + & + & + & - & + & + & + \\
\hline D-Xylose & - & - & - & - & - & + & + & - & + & NA & - & + \\
\hline Trehalose & + & $\mathrm{w}$ & $\mathrm{w}$ & + & + & - & + & + & + & + & + & + \\
\hline L-Xylose & - & - & - & - & - & $\mathrm{NA}$ & $\mathrm{NA}$ & - & NA & $\mathrm{NA}$ & NA & + \\
\hline Quinone(s) & $\begin{array}{l}\text { MK-7, } \\
\text { MK-6 }\end{array}$ & NA & $\mathrm{NA}$ & $\begin{array}{l}\text { MK-7, } \\
\text { MK-6 }\end{array}$ & $\begin{array}{l}\text { MK-7, } \\
\text { MK-6 }\end{array}$ & $\begin{array}{r}\text { MK-7, } \\
\text { MK-6 }\end{array}$ & $\begin{array}{r}\text { MK-7, } \\
\text { MK-6 }\end{array}$ & MK-7 & MK-7 & MK-7 & MK-7 & MK7 \\
\hline
\end{tabular}


Table 1. cont.

\begin{tabular}{|c|c|c|c|c|c|c|c|c|c|c|c|c|}
\hline Characteristic & 1 & 2 & 3 & 4 & 5 & 6 & 7 & 8 & 9 & 10 & 11 & 12 \\
\hline $\begin{array}{l}\text { DNA G }+ \text { C content } \\
(\mathrm{mol} \%)\end{array}$ & 43.5 & 46.5 & 44.0 & 44.0 & 46.0 & 46.1 & 42.4 & 40.4 & 43.4 & 44.4 & 47 & 43.7 \\
\hline
\end{tabular}

sequence divergence $(>3 \%)$ and a number of phenotypic and chemotaxonomic features (Table 1, Table 2 and Supplementary Table S1) distinguish them from other species of the genus Mucilaginibacter. Strains ANJLI2 $2^{\mathrm{T}}$, MP601 and RA1BR4 were nearly identical in their physiological, phylogenetic and chemotaxonomic characteristics and should be placed in the same species. Based on the phylogenetic, phenotypic and chemotaxonomic data, it is concluded that the strains represent three novel species of the genus Mucilaginibacter with the proposed names Mucilaginibacter frigoritolerans sp. nov., Mucilaginibacter lappiensis sp. nov. and Mucilaginibacter mallensis sp. nov.

Table 2. Cellular fatty acid composition (\%) of the novel isolates and the type strains of species of the genus Mucilaginibacter

Strains: 1, ANJLI2 ${ }^{\mathrm{T}}$; 2, RA1BR4; 3, MP601; 4, FT22 ${ }^{\mathrm{T}}$; 5, MP1X4 ${ }^{\mathrm{T}} ; 6$, M. paludis TPT56 ${ }^{\mathrm{T}}$ (data from Pankratov et al., 2007); 7, M. gracilis TPT18 ${ }^{\mathrm{T}}$ (Pankratov et al., 2007); 8, M. daejeonensis Jip $10^{\mathrm{T}}$ (An et al., 2009); 9, M. ximonensis XM-003 ${ }^{\mathrm{T}}$ (Luo et al., 2009); 10, M. oryzae B9 ${ }^{\mathrm{T}}$ (Jeon et al., 2009); 11, M. rigui WPCB133 ${ }^{\mathrm{T}}$ (Baik et al., 2010); 12, M. kameinonensis SCK ${ }^{\mathrm{T}}$ (Baik et al., 2010). tr, Trace $(<0.3 \%$ ); -, not detected.

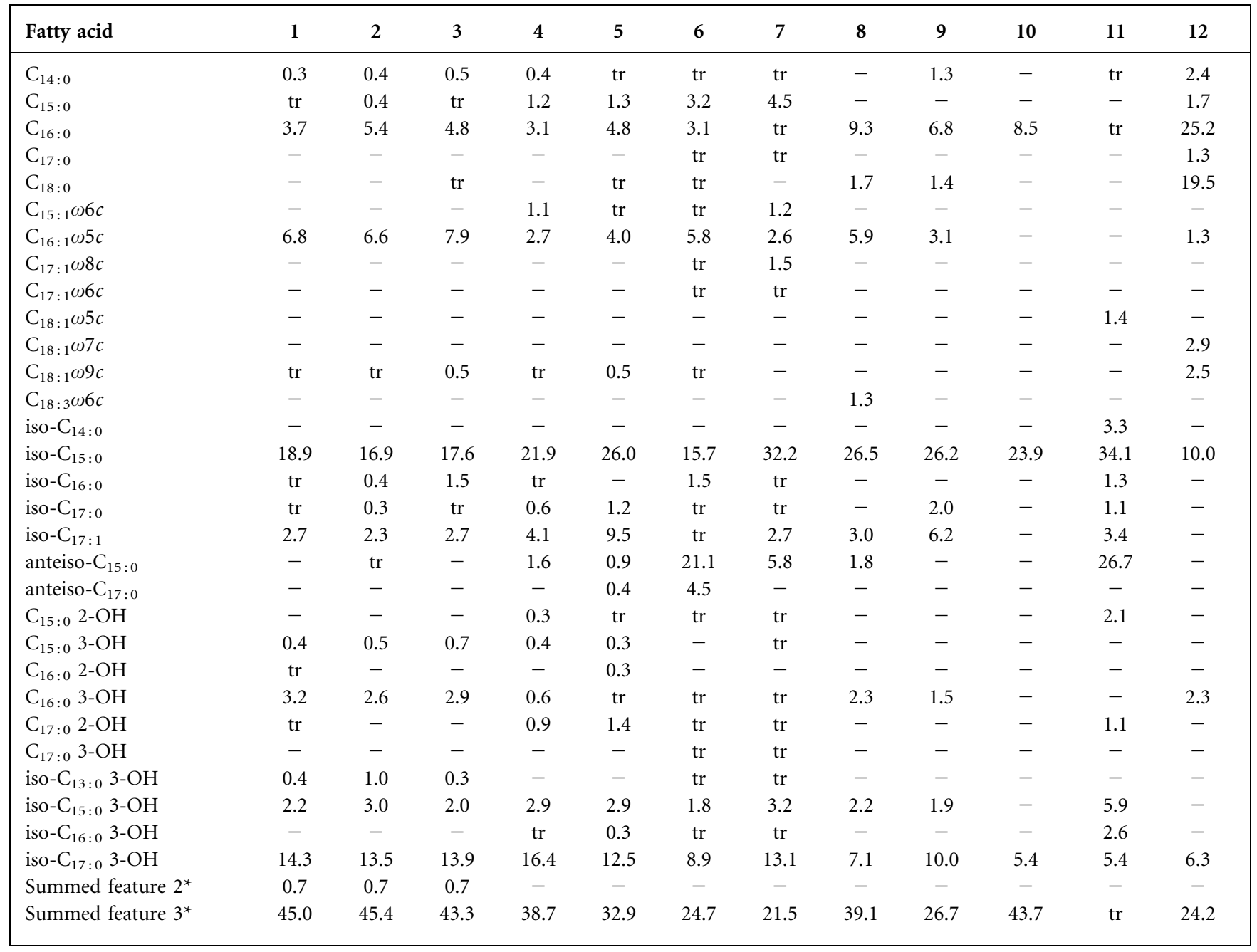

${ }^{*}$ Summed features: 2, iso- $\mathrm{C}_{16: 1}$ and/or $\mathrm{C}_{14: 0} 3-\mathrm{OH} ; 3, \mathrm{C}_{16: 1} \omega 7 c$ and/or iso- $\mathrm{C}_{15: 0} 2-\mathrm{OH}$. 


\section{Description of Mucilaginibacter frigoritolerans sp. nov.}

Mucilaginibacter frigoritolerans (fri.go.ri.to'le.rans. L. neut. $\mathrm{n}$. frigus, frigoris the cold; L. part. adj. tolerans tolerating; N.L. part. adj. frigoritolerans cold tolerating).

Cells are Gram-negative, non-motile rods, $0.3-0.5 \mu \mathrm{m}$ wide and 1-4 $\mu \mathrm{m}$ long, that occur singly or in pairs. Colonies on R2A agar are yellow, circular, convex and smooth. Grows at 0 to $33{ }^{\circ} \mathrm{C}$ and $\mathrm{pH} 5-7$, with optimum growth at $25{ }^{\circ} \mathrm{C}$ and $\mathrm{pH}$ 6. Growth is inhibited at $\mathrm{NaCl}$ concentrations $>1 \%$. Aerobic. Catalase- and oxidase-positive. Hydrolyses CM-cellulose, lichenin and aesculin, but not gelatin. Positive for acid production from L-arabinose, D-glucose, D-mannose, amygdalin, arbutin, salicin, cellobiose, maltose, lactose, melibiose, sucrose, trehalose, melezitose, gentiobiose and turanose. Negative for acid production from ribose, D-arabinose, D- and L-xylose, L-sorbose, Lrhamnose, dulcitol, inositol, mannitol, sorbitol, raffinose, starch, glycogen, xylitol, D-lyxose, D-tagatose, D- and Lfucose, and D- and L-arabitol. Weakly positive for acid production from galactose, D-fructose, $\mathrm{N}$-acetylglucosamine and inulin. Assimilates L-arabinose, cellobiose, D-glucosamine, maltose, D-mannose, sucrose, xylose, trehalose, D-galactose, D-arabinose, D-glucose and lactose, but not D-ribose, D-sorbitol, D-glycine, succinate, formate, Lornithine, glucuronate, maleic acid, pyruvate, acetate, mannitol, D- and L-alanine, or L-leucine. Positive for oxidation of the following Biolog GN2 microplate substrates: $\alpha$-cyclodextrin, dextrin, glycogen, $N$-acetyl-D-glucosamine, cellobiose, D-fructose, gentiobiose, $\alpha$-D-glucose, $\alpha$ lactose, lactulose, maltose, D-mannose, melibiose, methyl $\beta$-D-glucoside, sucrose, trehalose, turanose, L-alanylglycine, L-glutamic acid, L-proline, L-serine, L-threonine, glycerol, DL- $\alpha$-glycerol phosphate, $\alpha$-D-glucose 1-phosphate and $\alpha$-Dglucose 6-phosphate. Weakly positive for the oxidation of D-galactose. Negative for the oxidation of Biolog GN2 substrates acetic acid, $\mathrm{N}$-acetyl-D-galactosamine, cis-aconitic acid, adonitol, L-alaninamide, D- and L-alanine, $\gamma$-aminobutyric acid, 2-aminoethanol, L-arabinose, D-arabitol, L-asparagine, L-aspartic acid, bromosuccinic acid, 2,3-butanediol, D- and L-carnitine, citric acid, i-erythritol, formic acid, Lfucose, D-galactonic acid lactone, D-galacturonic acid, Dglucosaminic acid, glucuronamide, D-glucuronic acid, glycyl L-aspartic acid, glycyl L-glutamic acid, L-histidine, $\alpha$-, $\beta$ - and $\gamma$-hydroxybutyric acids, $p$-hydroxyphenylacetic acid, L-hydroxyproline, inosine, myo-inositol, itaconic acid, $\alpha$-ketobutyric acid, $\alpha$-ketoglutaric acid, $\alpha$-ketovaleric acid, D- and L-lactic acid, L-leucine, malonic acid, D-mannitol, L-ornithine, Lphenylalanine, phenylethylamine, propionic acid, D-psicose, putrescine, L-pyroglutamic acid, pyruvic acid methyl ester, quinic acid, raffinose, L-rhamnose, D-saccharic acid, sebacic acid, D-serine, D-sorbitol, succinamic acid, succinic acid, succinic acid monomethyl ester, thymidine, Tweens 40 and 80 , uridine, urocanic acid and xylitol. Produces alkaline phosphatase, esterase (C8), leucine arylamidase, valine arylamidase, acid phosphatase, naphthol-AS-BI-phosphohydrolase, $\alpha$-galactosidase, $\beta$-galactosidase, $\alpha$-glucosidase, $\beta$-glucosidase,
$N$-acetyl- $\beta$-glucosaminidase and $\alpha$-mannosidase, but not trypsin, $\alpha$-chymotrypsin, $\beta$-glucuronidase or $\alpha$-fucosidase. Weakly positive for the following activities (API ZYM): esterase (C4), lipase (C14) and cystine arylamidase. The major isoprenoid quinone is MK-7. The major cellular fatty acids are summed feature $3\left(\mathrm{C}_{16: 1} 1 \omega 7 c /\right.$ iso- $\left.\mathrm{C}_{15: 0} 2-\mathrm{OH}\right)$, iso$\mathrm{C}_{15: 0}$, iso- $\mathrm{C}_{17: 0} 3-\mathrm{OH}$, iso- $\mathrm{C}_{17: 1}, \mathrm{C}_{16: 0}$, iso- $\mathrm{C}_{15: 0} 3-\mathrm{OH}$ and $\mathrm{C}_{16: 1} \omega 5 c$.

The type strain is $\mathrm{FT}_{2} 2^{\mathrm{T}}\left(=\mathrm{ATCC}\right.$ BAA- $1854^{\mathrm{T}}=\mathrm{LMG}$ $25359^{\mathrm{T}}$ ), isolated from freeze-thaw treated tundra soil collected from Malla nature reserve, northern Finland. The DNA $\mathrm{G}+\mathrm{C}$ content of the type strain is $44.0 \mathrm{~mol} \%$.

\section{Description of Mucilaginibacter lappiensis sp. nov.}

Mucilaginibacter lappiensis [lap.pi.en'sis. N.L. masc. adj. lappiensis pertaining to Lapland (Finn. Lappi)].

Cells are Gram-negative, non-motile straight rods, 0.3$0.5 \mu \mathrm{m}$ wide and $1-3 \mu \mathrm{m}$ long, that occur singly or in pairs. Colonies grown on R2A agar are light pink to reddish, circular, convex and smooth. Growth occurs from 0 to $31{ }^{\circ} \mathrm{C}$ and at $\mathrm{pH} 4.5-8.0$, with optimum at $25{ }^{\circ} \mathrm{C}$ and $\mathrm{pH}$ 6. Growth is inhibited at $\mathrm{NaCl}$ concentrations $>1.5 \%$. Aerobic. Catalase- and oxidase-positive. Hydrolyses CMcellulose, lichenin, aesculin and gelatin, but not xylan. Positive for acid production from D-arabinose, D-galactose, D-glucose, amygdalin, salicin, cellobiose, maltose, lactose, melibiose, sucrose, trehalose, gentiobiose and L-fucose. Negative for acid production from ribose, L-arabinose, Dfructose, D- and L-xylose, L-sorbose, L-rhamnose, dulcitol, inositol, inulin, melezitose, mannitol, sorbitol, raffinose, starch, glycogen, xylitol, D-lyxose, turanose, D-tagatose, Dfucose, and D- and L-arabitol. Weakly positive for acid production from D-mannose, $\mathrm{N}$-acetylglucosamine and arbutin. Assimilates L-arabinose, cellobiose, D-glucosamine, maltose, D-mannose, sucrose, xylose, trehalose, D-galactose, D-arabinose, D-glucose and lactose, but not D-ribose, Dsorbitol, D-glycine, succinate, formate, L-ornithine, glucuronate, maleic acid, pyruvate, acetate, mannitol, D-alanine or L-leucine. Positive for oxidation of the following Biolog GN2 microplate substrates: dextrin, $N$-acetyl-D-galactosamine, $N$-acetyl-D-glucosamine, cellobiose, L-fucose, Dgalactose, gentiobiose, $\alpha$-D-glucose, $\alpha$-lactose, lactulose, maltose, D-mannose, melibiose, methyl $\beta$-D-glucoside, raffinose, sucrose, trehalose, turanose, L-alanine, L-alanylglycine, L-asparagine, L-glutamic acid, L-proline and glycerol. Weakly positive for oxidation of D-fructose, $\alpha$-Dglucose 1-phosphate, $\alpha$-D-glucose 6-phosphate, and D- and $\mathrm{L}-\alpha$-glycerol phosphate. Oxidation of D-gluconic acid and L-ornithine varies between strains. Negative for oxidation of the Biolog GN2 substrates acetic acid, cis-aconitic acid, adonitol, L-alaninamide, D-alanine, $\gamma$-aminobutyric acid, 2aminoethanol, L-arabinose, D-arabitol, L-aspartic acid, bromosuccinic acid, 2,3-butanediol, D- and L-carnitine, citric acid, $\alpha$-cyclodextrin, i-erythritol, formic acid, Dgalactonic acid lactone, D-galacturonic acid, D-glucosaminic 
acid, glucuronamide, glycogen, glycyl L-aspartic acid, glycyl L-glutamic acid, L-histidine, $\alpha$-, $\beta$ - and $\gamma$-hydroxybutyric acids, $p$-hydroxyphenylacetic acid, L-hydroxyproline, inosine, myo-inositol, itaconic acid, $\alpha$-ketobutyric acid, $\alpha$ ketoglutaric acid, $\alpha$-ketovaleric acid, D- and L-lactic acid, malonic acid, D-mannitol, L-phenylalanine, phenylethylamine, propionic acid, D-psicose, putrescine, L-pyroglutamic acid, pyruvic acid methyl ester, quinic acid, L-rhamnose, Dsaccharic acid, sebacic acid, D-serine, D-sorbitol, succinamic acid, succinic acid, succinic acid monomethyl ester, thymidine, Tweens 40 and 80, uridine, urocanic acid and xylitol. Produces alkaline phosphatase, esterase (C8), leucine arylamidase, valine arylamidase, cystine arylamidase, trypsin, acid phosphatase, naphthol-AS-BI-phosphohydrolase, $\alpha$ galactosidase, $\beta$-galactosidase, $\alpha$-glucosidase, $\beta$-glucosidase, $N$-acetyl- $\beta$-glucosaminidase, $\alpha$-mannosidase and $\alpha$-fucosidase, but not $\alpha$-chymotrypsin or lipase. Weakly positive (API $\mathrm{ZYM}$ ) for esterase (C4) and $\beta$-glucuronidase. The major isoprenoid quinone is MK-7. The major cellular fatty acids are summed feature $3\left(\mathrm{C}_{16: 1} \omega 7 \mathrm{c} /\right.$ iso- $\left.\mathrm{C}_{15: 0} 2-\mathrm{OH}\right)$, iso- $\mathrm{C}_{15: 0}$, iso- $\mathrm{C}_{17: 0} 3-\mathrm{OH}, \mathrm{C}_{16: 1} \omega 5 c, \mathrm{C}_{16: 0}, \mathrm{C}_{16: 0} 3-\mathrm{OH}$ and iso- $\mathrm{C}_{17: 1}$ The DNA G + C content is $43.5-46.5 \mathrm{~mol} \%$.

The type strain is ANJLI2 ${ }^{\mathrm{T}}\left(=\right.$ ATCC BAA- $1855^{\mathrm{T}}=\mathrm{LMG}$ $25358^{\mathrm{T}}$ ), isolated from decaying lichen collected in an oligotrophic Scots pine forest at Angeli, Northern Finland. Two reference strains are MP601 and RA1BR4.

\section{Description of Mucilaginibacter mallensis sp. nov.}

Mucilaginibacter mallensis (mal.len'sis. N.L. masc. adj. mallensis pertaining to Malla Nature Reserve, Finland).

Cells are Gram-negative, non-motile, straight rods, 0.4$0.6 \mu \mathrm{m}$ wide and $1-2 \mu \mathrm{m}$ long that occur singly or in pairs. Colonies grown on R2A agar are yellow, circular, convex and smooth. Growth occurs between -3 and $33{ }^{\circ} \mathrm{C}$ and at $\mathrm{pH} 4.5-7.0$, with optimum at $25{ }^{\circ} \mathrm{C}$ and $\mathrm{pH}$ 6. Growth is inhibited at $\mathrm{NaCl}$ concentrations $>1 \%$. Catalase- and oxidase-positive. Hydrolyses CM-cellulose, xylan and aesculin, but not gelatin or lichenin. Reduces nitrate to nitrite. Positive for acid production from L-arabinose, galactose, Dglucose, D-fructose, D-mannose, amygdalin, arbutin, salicin, cellobiose, maltose, lactose, melibiose, sucrose, trehalose, inulin, raffinose and gentiobiose. Negative for acid production from ribose, D-arabinose, D- and L-xylose, L-sorbose, Lrhamnose, dulcitol, inositol, mannitol, melezitose, sorbitol, glycogen, xylitol, D-lyxose, D-tagatose, turanose, D- and Lfucose, and D- and L-arabitol. Weakly positive for acid production from $\mathrm{N}$-acetylglucosamine and starch. Assimilates D- and L-arabinose, cellobiose, D-glucosamine, maltose, D-mannose, sucrose, xylose, trehalose, D-galactose, D-glucose and lactose, but not D-ribose, D-sorbitol, Dglycine, succinate, formate, L-ornithine, glucuronate, maleic acid, pyruvate, acetate, mannitol, D- and L-alanine, or L-leucine. Positive for oxidation of the following Biolog GN2 microplate substrates: $\alpha$-cyclodextrin, $N$-acetyl-D-glucosamine, cellobiose, D-fructose, D-galactose, gentiobiose, $\alpha$-D-glucose, $\alpha$-lactose, maltose, D-mannose, melibiose, methyl $\alpha$-D-glucoside, sucrose, trehalose, turanose, L-alanylglycine, L-glutamic acid and glycerol. Weakly positive for the oxidation of L-fucose, L-proline and L-threonine. Negative for oxidation of the Biolog GN2 substrates acetic acid, $\mathrm{N}$ acetyl-D-galactosamine, cis-aconitic acid, adonitol, L-alaninamide, $\mathrm{D}$ - and L-alanine, $\gamma$-aminobutyric acid, 2 -aminoethanol, L-arabinose, D-arabitol, L-asparagine, L-aspartic acid, bromosuccinic acid, 2,3-butanediol, D- and L-carnitine, citric acid, dextrin, i-erythritol, formic acid, D-galactonic acid lactone, D-galacturonic acid, D-gluconic acid, Dglucosaminic acid, glucose 1-phosphate, glucose 6-phosphate, glucuronamide, D-glucuronic acid, D- and L- $\alpha$ glycerol phosphate, glycogen, glycyl L-aspartic acid, glycyl L-glutamic acid, L-histidine, $\alpha$-, $\beta$ - and $\gamma$-hydroxybutyric acids, $p$-hydroxyphenylacetic acid, L-hydroxyproline, inosine, myo-inositol, itaconic acid, $\alpha$-ketobutyric acid, $\alpha$ ketoglutaric acid, $\alpha$-ketovaleric acid, D- and L-lactic acid, Lleucine, malonic acid, D-mannitol, L-ornithine, L-phenylalanine, phenylethylamine, propionic acid, D-psicose, putrescine, L-pyroglutamic acid, pyruvic acid methyl ester, quinic acid, raffinose, L-rhamnose, D-saccharic acid, sebacic acid, D- and L-serine, D-sorbitol, succinamic acid, succinic acid, succinic acid monomethyl ester, thymidine, Tweens 40 and 80, uridine, urocanic acid and xylitol. Produces alkaline phosphatase, esterase (C8), leucine arylamidase, valine arylamidase, acid phosphatase, naphthol-AS-BI-phosphohydrolase, $\alpha$-galactosidase, $\beta$-galactosidase, $\alpha$-glucosidase, $N$-acetyl- $\beta$-glucosaminidase and $\alpha$-fucosidase, but not lipase, cystine arylamidase, trypsin or $\alpha$-chymotrypsin. Weakly positive for the following activities (API ZYM): esterase (C4), $\beta$-glucosidase, $\beta$-glucuronidase and $\alpha$-mannosidase. The major isoprenoid quinone is MK-7. The major cellular fatty acids are summed feature $3\left(\mathrm{C}_{16: 1} \omega 7 \mathrm{c} /\right.$ iso$\left.\mathrm{C}_{15: 0} 2-\mathrm{OH}\right)$, iso- $\mathrm{C}_{15: 0}$, iso- $\mathrm{C}_{17: 0} 3-\mathrm{OH}$, iso- $\mathrm{C}_{17: 1}, \mathrm{C}_{16: 0}$, iso- $\mathrm{C}_{15: 0} 3-\mathrm{OH}$ and $\mathrm{C}_{16: 1} \omega 5 c$.

The type strain is MP1X4 $4^{\mathrm{T}}$ (=ATCC BAA- $1856^{\mathrm{T}}=\mathrm{LMG}$ $25360^{\mathrm{T}}$ ), isolated from tundra soil of a wind-exposed ridge in Malla nature reserve, northern Finland. The DNA G +C content of the type strain is $46.0 \mathrm{~mol} \%$.

\section{Acknowledgements}

This work was supported by the Academy of Finland (grants 106208 and 123725) and the National Science Foundation (IPY 0732956). We thank Hilkka Reunanen and Tarmo Suppula for the help in electron microscopy. Professor Hans Trüper is gratefully acknowledged for the help with Latin for new species names.

\section{References}

Altschul, S. F., Madden, T. L., Schäffer, A. A., Zhang, J., Zhang, Z., Miller, W. \& Lipman, D. J. (1997). Gapped BLAST and PSI-BLAST: a new generation of protein database search programs. Nucleic Acids Res 25, 3389-3402.

An, D.-S., Yin, C.-R., Lee, S.-T. \& Cho, C.-H. (2009). Mucilaginibacter daejeonensis sp. nov., isolated from dried rice straw. Int J Syst Evol Microbiol 59, 1122-1125. 
Baik, K. S., Park, S. C., Kim, E. M., Lim, C. H. \& Seong, C. N. (2010). Mucilaginibacter rigui sp. nov., isolated from wetland freshwater, and emended description of the genus Mucilaginibacter. Int J Syst Evol Microbiol 60, 134-139.

Bernardet, J.-F., Nakagawa, Y. \& Holmes, B. (2002). Proposed minimal standards for describing new taxa of the family Flavobacteriaceae and emended description of the family. Int J Syst Evol Microbiol 52, 1049-1070.

Jeon, Y., Lee, S.-S., Chung, B. S., Kim, J. M., Bae, J.-W., Park, S. K. \& Jeon, C. O. (2009). Mucilaginibacter oryzae sp. nov., isolated from soil of a rice paddy. Int J Syst Evol Microbiol 59, 1451-1454.

Kerkhof, L. \& Ward, B. B. (1993). Comparison of nucleic acid hybridization and fluorometry for measurement of the relationship between RNA/DNA ratio and growth rate in a marine bacterium. Appl Environ Microbiol 59, 1303-1309.

Luo, X., Zhang, L., Dai, J., Liu, M., Zhang, K., An, H. \& Fang, C. (2009). Mucilaginibacter ximonensis sp. nov., isolated from Tibetan soil. Int $J$ Syst Evol Microbiol 59, 1447-1450.

Männistö, M. K. \& Häggblom, M. M. (2006). Characterization of psychrotolerant heterotrophic bacteria from Finnish Lapland. Syst Appl Microbiol 29, 229-243.

Männistö, M. K., Tiirola, M. \& Häggblom, M. (2009). Effect of freezethaw cycles on bacterial communities of Arctic tundra soil. Microb Ecol 58, 621-631.

Margesin, R., Spröer, C., Schumann, P. \& Schinner, F. (2003). Pedobacter cryoconitis sp. nov., a facultative psychrophile from alpine glacier cryoconite. Int J Syst Evol Microbiol 53, 1291-1296.

Mesbah, M., Premachandran, U. \& Whitman, W. B. (1989). Precise measurement of the $\mathrm{G}+\mathrm{C}$ content of deoxyribonucleic acid by high-performance liquid chromatography. Int J Syst Bacteriol 39, 159-167.

Murray, R. G. E., Doetsch, R. N. \& Robinow, F. (1994). Determinative and cytological light microscopy. In Methods for General and Molecular Bacteriology, pp. 21-41. Edited by P. Gerhardt, R. G. E. Murray, W. A. Wood \& N. R. Krieg. Washington, DC: American Society for Microbiology.

Pankratov, T. A., Tindall, B. J., Liesack, W. \& Dedysh, S. N. (2007). Mucilaginibacter paludis gen. nov., sp. nov. and Mucilaginibacter gracilis sp. nov., pectin-, xylan- and laminarin-degrading members of the family Sphingobacteriaceae from acidic Sphagnum peat bog. Int $J$ Syst Evol Microbiol 57, 2349-2354.

Sait, M., Hugenholtz, P. \& Janssen, P. H. (2002). Cultivation of globally distributed soil bacteria from phylogenetic lineages previously only detected in cultivation-independent surveys. Environ Microbiol 4, 654-666.

Shivaji, S., Chaturvedi, P., Reddy, G. S. N. \& Suresh, K. (2005). Pedobacter himalayensis sp. nov., from the Hamta glacier located in the Himalayan mountain ranges of India. Int J Syst Evol Microbiol 55, 1083-1088.

Tamura, K., Nei, M. \& Kumar, S. (2004). Prospects for inferring very large phylogenies by using the neighbor-joining method. Proc Natl Acad Sci U S A 101, 11030-11035.

Tamura, K., Dudley, J., Nei, M. \& Kumar, S. (2007). MEGA4: molecular evolutionary genetics analysis (MEGA) software version 4.0. Mol Biol Evol 24, 1596-1599.

Urai, M., Aizawa, T., Nakagawa, Y., Nakajima, M. \& Sunairi, M. (2008). Mucilaginibacter kameinonensis sp. nov., isolated from garden soil. Int J Syst Evol Microbiol 58, 2046-2050. 